\title{
Hydrologic Response of Meadow Restoration the First Year Following Removal of Encroached Conifers
}

\author{
Christopher Surfleet ${ }^{1, *(\mathbb{D}}$, Thomas Sanford ${ }^{1}$, Gregory VanOosbree ${ }^{1(\mathbb{D}}$ and John Jasbinsek ${ }^{2}$ () \\ 1 Natural Resources Management and Environmental Science Department, California Polytechnic State \\ University, San Luis Obispo, CA 93407, USA; thomas.sanford7@gmail.com (T.S.); \\ gregvanoosbree@yahoo.com (G.V.) \\ 2 Physics Department, California Polytechnic State University, San Luis Obispo, CA 93407, USA; \\ jjasbins@calpoly.edu \\ * Correspondence: csurflee@calpoly.edu; Tel.: +01-805-756-2743
}

Received: 4 January 2019; Accepted: 27 February 2019; Published: 28 February 2019

\begin{abstract}
This study examines the hydrologic response of a montane meadow the first winter following restoration by removal of encroached conifers. Hydrologic change was evaluated through statistical comparison of soil moisture and water table depths between the restored meadow, Marian Meadow, and a Control Meadow before and after restoration. Meadow water budgets and durations of water table depths during the growing season were evaluated. Electrical resistivity tomography profiles were collected to improve the spatial interpretation of subsurface water beyond well measurements. The first year following restoration Marian Meadow had a statistically significant increase in volumetric soil moisture content of $4 \%$ with depth to the water table decreasing on average by $0.15 \mathrm{~m}$. The water budget for the meadows demonstrated that the hydrologic change following removal of encroached conifers was primarily due to a reduction of vegetation interception capture. Soil evapotranspiration rates in both the Control and Marian Meadows were relatively stable ranging from 268-288 mm/yr with the exception of the year following conifer removal in Marian Meadow with $318 \mathrm{~mm} / \mathrm{yr}$. The increase in soil evapotranspiration in the first post restoration year is attributed to loss of vegetation cover and higher proportions of bare soil created from the harvest operations. The duration of post-restoration water table depths during the growing season at Marian Meadow were less than or equal to $0.7 \mathrm{~m}$ and $0.3 \mathrm{~m}$ for 85 days and 50 days, respectively, indicating hydrologic conditions conducive to meadow vegetation.
\end{abstract}

Keywords: conifer encroachment; meadow restoration; meadow hydrology; electrical resistivity; water yield

\section{Introduction}

Meadows are a small but important component of forested ecosystems in temperate climates. They provide critical habitat for many species of plants and animals [1-3] and play an important role in improving water quality, flood protection, and carbon storage [4]. Over the last century, Sierra Nevada and Cascade mountain meadows have reduced in size and number in part due to conifer encroachment. Temperate forest regions in Europe and Canada have also seen declines in montane meadows due to conifer encroachment $[5,6]$. However, there is little information on the hydrologic effect of removing encroached conifers for meadow restoration.

Conifer encroachment (also referred to as invasion) refers to the migration of conifers into meadow biotic communities. In the western United States, encroachment is typically by an influx of Pinus contorta, commonly known as lodgepole pine, due to its tolerance of a wide range of hydrologic conditions [7]. In areas where it has been assessed, such as the Cascade Mountains of central Oregon, 
USA, meadow habitat has decreased by nearly $50 \%$; decreasing from $5.5 \%$ of the regions habitat to $2.5 \%$ [8]. Currently, in the Sierra Nevada, approximately $60 \%$ of montane meadows in Sequoia Kings Canyon National Park, USA and upwards of $42 \%$ of meadows in the Lake Tahoe Basin, USA contain both saplings and seedlings of lodgepole pine [9]. In Lassen National Park, USA, conifer encroachment in meadows accelerated following cessation of grazing and burning associated with the parks establishment in 1916 through 1933 [10]. In a similar time period, there has been a decline in the area of montane meadows by up to $45 \%$ in the Polish Carpathians [5]. However European meadow encroachment are associated with other woody species: for example Norway spruce (Picea abies), Juniper (Juniperus communis), or mountain pine (Pinus muga).

Lodgepole pine's tolerance for a wide range of hydrologic conditions plays a key role in its ability to colonize meadows while other tree species maintain their current position [9]. Fire suppression in Sierra Nevada and Cascade mountain forests has resulted in decreased fire frequency, creating an increase in the density of mid-elevation pine forest and subsequent encroachment of lodgepole pine into meadows [11,12].

In the western United States, meadows are classified by moisture gradient defined as either: wet, mesic, dry or sagebrush meadows based primarily on depth to the water table [13]. Meadows that receive the majority of their water from upland groundwater and surface water sources often exhibit elevated water table depths throughout the growing season. As a result they tend to support a high proportion of obligate, facultative, and facultative wetland plant species. Meadows that receive the majority of their water surplus from precipitation, such as dry meadows, are usually dominated by facultative and facultative upland plant species [14]. This generally means that dry meadows have a shallow water table during limited periods following precipitation events and snowmelt (3-6 months of the year). These meadow types may occur in a variety of geomorphic settings, but must be able to retain moisture near the soil surface long enough following precipitation and snowmelt to enable perennial meadow flora to flower and reproduce [15].

In a study that reviewed growing season water table depths among various meadow community types, it was determined that the growing season water table depth ranged from 0.4 to $1.25 \mathrm{~m}$ and 0.17 to $0.62 \mathrm{~m}$ for plant communities common in dry and wet meadows respectively [15]. The duration of time that the water table is near the surface also influences vegetation community and meadow types [15].

A warming climate suggests that snowpack will melt earlier in the year and more winter precipitation will occur as rain in mountain environments [16-18]. A consequence of projected decreases in annual snowpack will be diminished groundwater recharge in the spring and summer as a larger quantity of water moves through mountain watersheds as surface runoff following rain precipitation events [19]. In mountainous terrain, a deeper seasonal water table and decreased periods of near surface field capacity will stress meadow vegetation with high transpiration rates and promote the colonization of meadows by non-meadow species [20]. If current climate trends continue increased stress on meadow habitat will occur and conifer encroachment may represent a transition to a new stable state rather than a temporary vegetative fluctuation [21]. Similar challenges have been reported in temperate montane meadows in Europe, notably in the Carpathian Mountains [5]. The many stresses on montane meadows suggest active management, such as removal of encroaching conifers, is needed to maintain meadow habitat.

Successful restoration of meadows is characterized by a higher seasonal water table, increases in seasonal soil moisture, and a return of endemic meadow species [22]. Many studies have addressed the effects of tree removal on stream discharge, water yield, and soil moisture [23-25]. The majority of surveyed research indicates that vegetation removal has a quantifiable effect on the hydrology of a watershed, during at least the initial years following removal prior to vegetation re-growth. Soil water exerts the most influential control on the vegetative composition of meadows and wetlands [26]. Therefore it is crucial to quantify the hydrologic response associated with conifer removal in encroached meadows for planning restoration strategies. 
This manuscript quantifies the hydrologic response of a meadow, Marian Meadow, the first year following restoration by removal of encroaching conifers. The research at Marian Meadow is ongoing and will eventually quantify the long term hydrologic response. The research objectives for these first year results are: (1) Make a statistical comparison of meadow soil moisture and groundwater depth measurements pre- and post-restoration. (2) Compare number of days of published groundwater depths compatible with meadow vegetation before and after restoration. (3) Compare differences in the water budget of the meadow pre- and post-restoration. We present this information to assist future meadow restoration efforts associated with encroached lodgepole pine removal.

\section{Materials and Methods}

\subsection{Study Areas}

The two study meadows were located approximately $16 \mathrm{~km}$ from Chester, California, USA on private forest land owned by Collins Pine Company (Table 1; Figure 1). The Control Meadow, 81 hectares in area and elevation $1460 \mathrm{~m}$, is a restored meadow. Marian Meadow is approximately 182 hectares in area at an elevation of $1370 \mathrm{~m}$. Marian Meadow was encroached primarily by lodgepole pine with a basal area of $25.04 \mathrm{~m}^{2} /$ hectare prior to restoration. Based on the approximate age of the trees on the meadow, encroachment of the meadow occurred over the last 50-75 years. The restoration of Marian Meadow involved removing all lodgepole pine from the meadow during the summer of 2015. The Control Meadow was restored by removing encroached conifers in 2010. Although recently restored, herbaceous meadow vegetation had filled in the 3 years prior to our study. This lead to an assumption that the Control Meadow was functioning similarly to an intact meadow. The close proximity of the Control Meadow to Marian Meadow, $9 \mathrm{~km}$ apart, the similar topography and elevation allowed the assumption that both meadows were subject to the same climate influences. In both meadows select mature trees of Pinus ponderosa were retained for wildlife purposes. Indigenous bunch and tuft grasses were the primary herbaceous vegetation in both meadows, however the relative density was lower in Marian Meadow the first year following restoration. (Table 1; Figure 2).

Table 1. Characteristics of Marian Meadow and Control Meadow.

\begin{tabular}{ccc}
\hline & Marian Meadow & Control Meadow \\
\hline Coordinates (decimal degrees, & $40.2636 \mathrm{~N} 121.3157 \mathrm{~W}$ & $40.2639 \mathrm{~N} 121.3945 \mathrm{~W}$ \\
latitude and longitude) & 18.2 & 8.1 \\
Area of meadow (ha) & 1370 & 1460 \\
Elevation (m) & Clay $(32-26-42)$ & Clay Loam $(47-16-37)$ \\
Surface soil texture & $47 \%$ & $42 \%$ \\
(\%sand-\%silt-\%clay) & $1.40 \mathrm{~g} / \mathrm{cm}^{3}$ & $1.53 \mathrm{~g} / \mathrm{cm}^{3}$ \\
Soil porosity at 30 cm depth & $60 \mathrm{~m} /$ day & $35 \mathrm{~m} /$ day \\
Bulk density at 30 cm depth & $\geq 12 \mathrm{~m}$ & Below detection limit of electrical \\
Hydraulic conductivity (2 m) & resistivity tomography (ERT) \\
Depth to a partially confining layer &
\end{tabular}



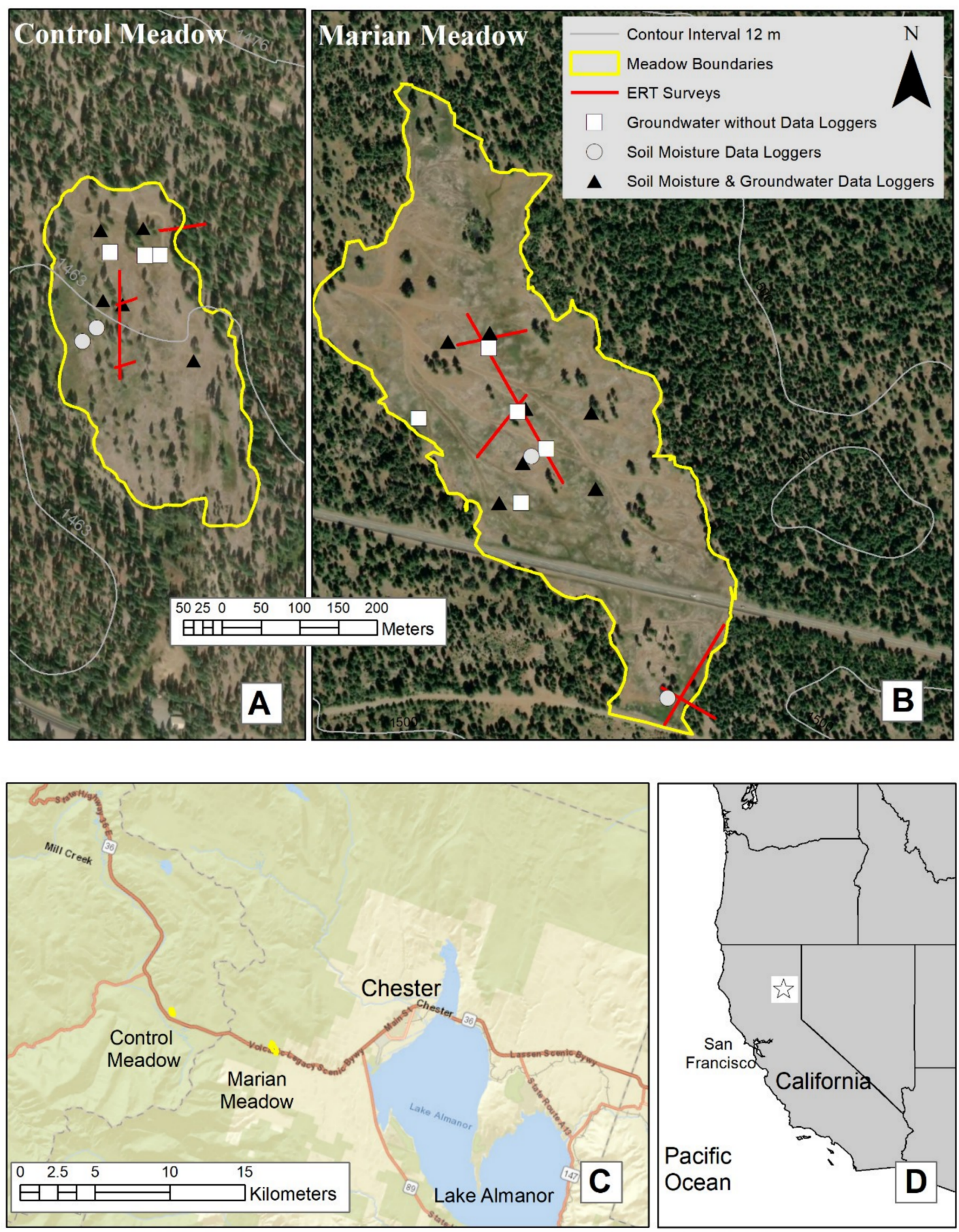

Figure 1. Marian Meadow and Control Meadow study areas. Locations of soil moisture, groundwater depth, and electrical resistivity tomography (ERT) measurements shown. (A) Control Meadow. (B) Marian Meadow. (C) Meadows in relation to city of Chester and Lake Almanor; California State Route 36 is adjacent to both meadows. (D) Study sites in relation to California, USA. Satellite imagery and base maps from Earth System Research Institute (ESRI).

The majority of precipitation in the study area occurs from November to April. The average yearly historical precipitation recorded at Chester is $860 \mathrm{~mm}$ [27]. The average yearly mean air temperature of nearby Chester, California (elevation $1372 \mathrm{~m}$ ) from 1948 to 2005 was $8.7^{\circ} \mathrm{C}$. Depending on climatic fluctuations, a proportion of this precipitation occurs as snow. During the 2014 and 2015 water years 
(WY), annual precipitation was below average at $489 \mathrm{~mm}$ and $636 \mathrm{~mm}$ respectively. The $2016 \mathrm{WY}$ had above average annual precipitation with $931 \mathrm{~mm}$.

The meadows are located in a transitional zone between the Cascade and Sierra Nevada Mountains, USA. Soils are derived primarily from volcanic material, yielding soil orders such as Alfisols, Mollisols, and Inceptisols [28]. The soil at Marian Meadow has a clay texture (Table 1). The Control Meadow consists of a clay loam from poorly consolidated alluvial materials with high sand content [29,30]. Soil bulk density and porosity were determined from samples taken at $30 \mathrm{~cm}$. Hydraulic conductivity was determined at $2 \mathrm{~m}$ using the Kozeny-Carmen equation [31] based on a particle size distribution analysis [32] (Table 1). Both meadows are dry meadows based on classifications by Chambers et al. [13] and Weixelman et al. [14].

A)

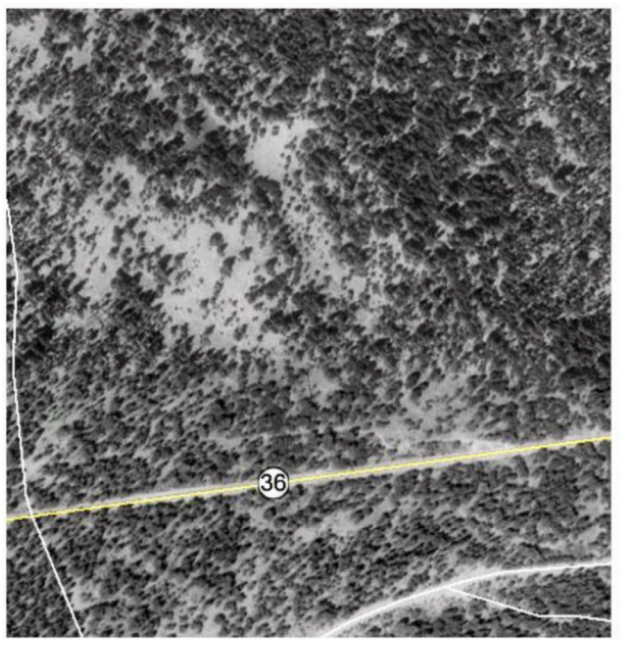

B)

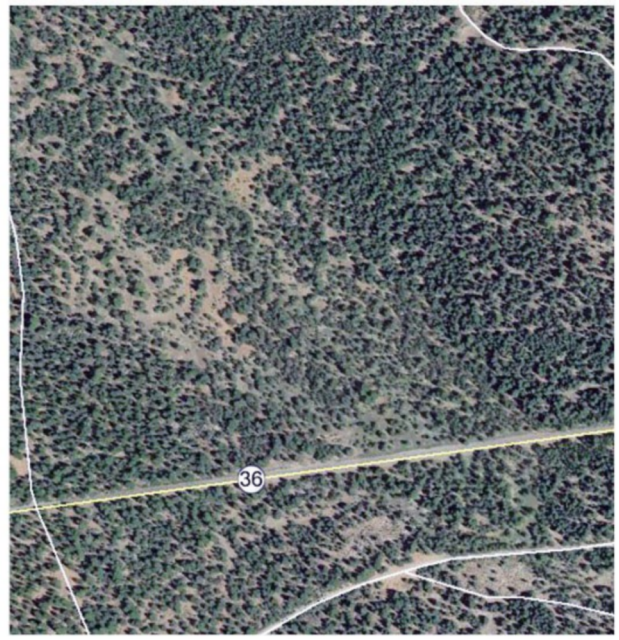

C)

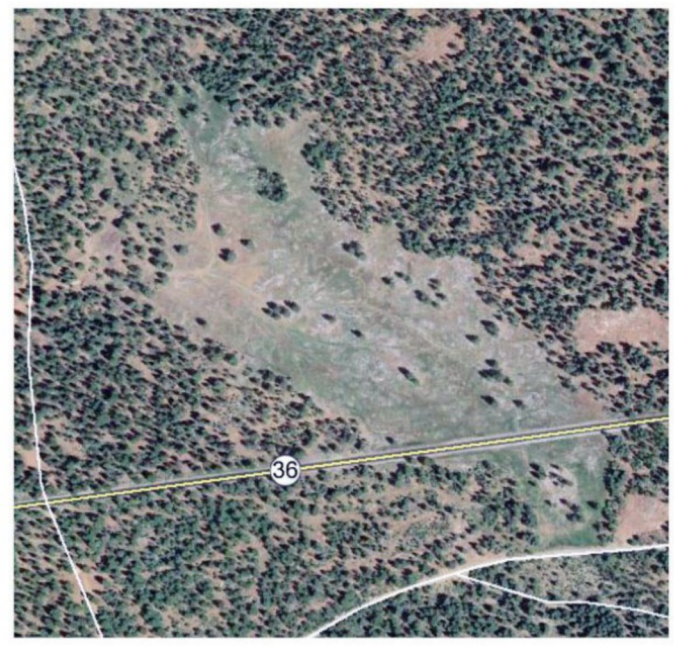

Figure 2. Marian Meadow with increasing lodgepole pine encroachment prior to restoration and following restoration from removal of encroached lodgepole pine (Imagery from Google Earth). California State Route 36 in image provides the spatial reference of the location (see Figure 1) (A) Marian Meadow at July, 1993; 12 years prior to restoration. (B) Marian Meadow May, 2014; 1 year prior to restoration. (C) Marian Meadow July, 2017; 2 years after restoration.

\subsection{Study Design}

To detect a change in hydrologic processes from restoration a before after control intervention (BACI) study design was used [13,14,33,34]. Measurements of soil moisture and groundwater depth 
were collected on the Marian Meadow and the Control Meadow approximately two years prior to restoration, starting September 2013 (Figure 1). Removal of encroached conifers within the Marian Meadow study area occurred during July 2015 (Figures 2 and 3). In this manuscript we evaluated a change in sub-surface hydrology and the water balance from the removal of the encroached conifers for 2014-2015 WY before conifer removal and 2016 WY, one year following conifer removal. We evaluated changes in sub-surface hydrology through statistical comparison of soil moisture and water table depths and duration of water table depth compared to published depth to water table for meadow vegetation. We evaluated the water budget of the meadows following methods in Rahgozar et al. [35].

A)

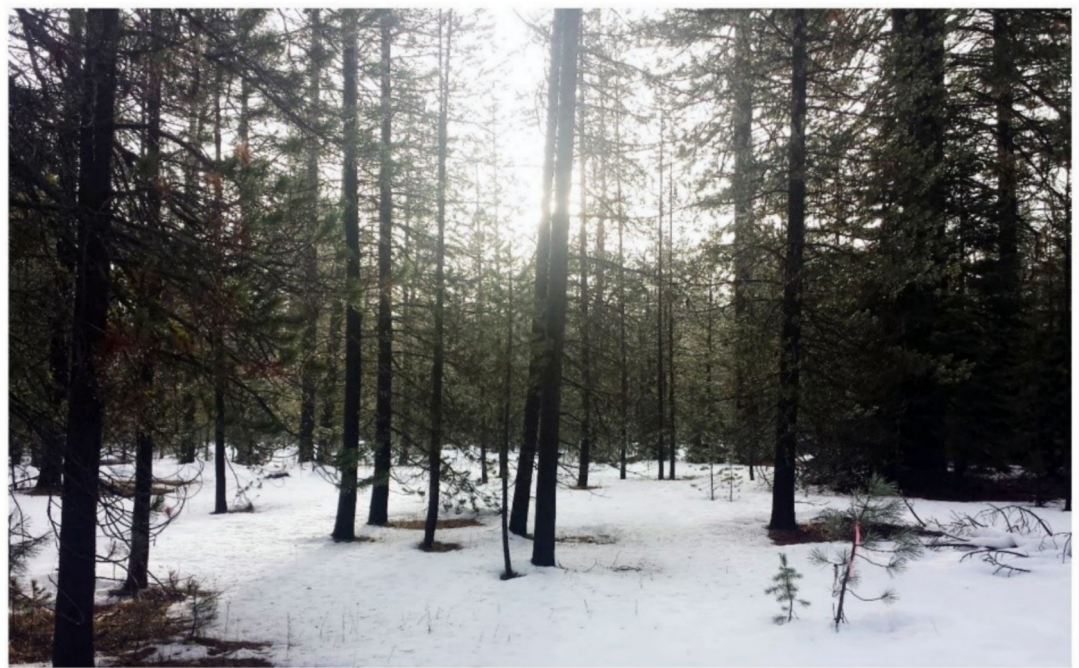

B)

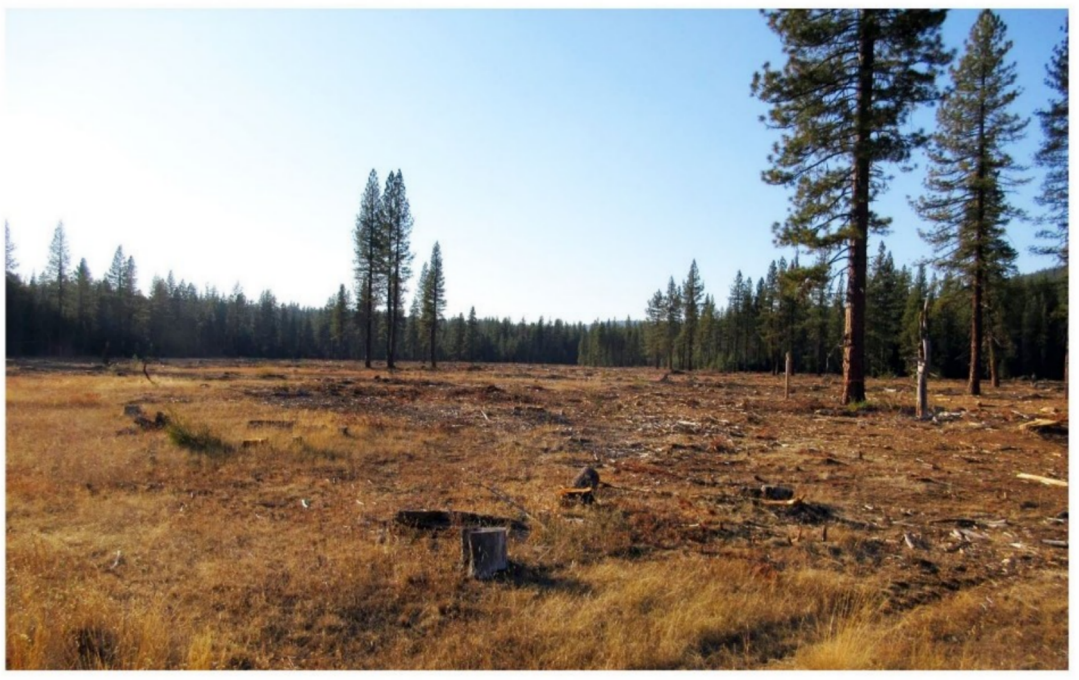

Figure 3. Marian Meadow before and after restoration to remove encroached lodgepole pine; view is looking north from California Route 36. (A) Marian Meadow with encroached conifers; December 2014. (B) Marian Meadow after restoration; September 2015.

\subsection{Volumetric Soil Moisture}

Gravimetric soil moisture measurements were taken at $0.3 \mathrm{~m}$ (2014-2016 WY) and $0.9 \mathrm{~m}$ depths (2015-2016 WY) below the ground surface using Odyssey soil moisture sensors manufactured by Dataflow Systems Pty Limited (Christchurch, New Zealand) and time domain reflectometry (TDR) soil 
moisture sensors sold by Onset Computer Corp (Bourne, MA, USA). The initial year of study Odyssey soil moisture sensors were used, in subsequent years Onset TDR soil moisture sensors were added to increase the spatial and depth distribution of measurements. The Odyssey soil moisture instruments were calibrated prior to installation using a 2-point calibration of: (1) no moisture and, (2) a known moisture content. The Onset TDR soil moisture sensors were factory calibrated. Soil moisture was recorded in 2-hour intervals. A total of ten soil moisture sensors were placed in each meadow (Figure 1). Gravimetric soil moisture measurements were converted to volumetric soil moisture using an empirical relation between the density of water and bulk density of soil determined by the core method [36].

\subsection{Water Table Depth}

Water level loggers manufactured by Odyssey Dataflow Systems Pty. Limited were installed on the meadows within shallow groundwater wells to a depth of $1.5 \mathrm{~m}$. There were a total of seven shallow groundwater wells with data loggers and five without loggers on Marian Meadow. There were five shallow groundwater wells with data loggers and three without loggers on the Control Meadow (Figure 1). Data loggers recorded groundwater depths at 2-hour intervals. Wells without loggers were sounded periodically when field personnel were visiting the meadows.

Electrical resistivity tomography (ERT) was used to improve the spatial extrapolation of groundwater depth and define groundwater level below the depth of shallow groundwater well detection. ERT is a geophysical method that detects spatial variations in the electrical resistivity of subsurface geologic materials [37]. Variations in electrical resistivity are interpreted for subsurface geologic structure, composition, and conditions, such as depth to groundwater. Because values of electrical resistivity in different geologic materials are not necessarily unique, understanding local geologic conditions is essential for interpretation of ERT data. All field measurements of apparent resistivity employed an automated Wenner array style on the resistivity meter (Syscal Kid Switch manufactured by IRIS Instruments, Orléans, France), which automates the data collection along the 24-electrode string. Apparent resistivity field data were inverted for a subsurface resistivity model with RES2DINV, ver. 3.71, (Geotomo Software, Penang, Malaysia), and exported to Matlab R2016a, (MathWorks, Natick, MA, USA), for plotting. The Wenner array geometry provides good resolution in horizontally layered structures, expected for the shallow water tables in the meadows. Groundwater depths were interpreted from the ERT images by identifying the depth at which a rapid change with depth to lower electrical resistivity values were observed.

Using the shallow groundwater wells alone, the water table depth could not be determined during periods when the water table receded below the $1.5 \mathrm{~m}$ detection depth of the wells. A recession curve analysis that accounted for weekly precipitation was used to predict water table depth during periods when the water table was below the well depth [25] (Equation (1)).

$$
d_{o}=k d_{t}^{t}+P
$$

where $d_{o}(\mathrm{~m})$ is the initial depth of the water table, $k$ is the recession coefficient, $d_{t}(\mathrm{~m})$ is the depth at the time interval, $t$ is the time interval of 1 week, and $P$ is precipitation $(\mathrm{m})$.

The recession coefficient was fit to periodic water table depth depths interpreted from ERT images. For example, Figure 4 was interpreted to have a water table depth of $2.5 \mathrm{~m}$. The recession coefficient was fit during the time when the $1.5 \mathrm{~m}$ well went dry to the $2.5 \mathrm{~m}$ water table depth from the ERT image. ERT images further validated the spatial continuity of the water table depths among wells in the meadows. Figure 4 demonstrates a reasonably smooth water table surface, this same smooth water table elevation was seen in the well measurements. 


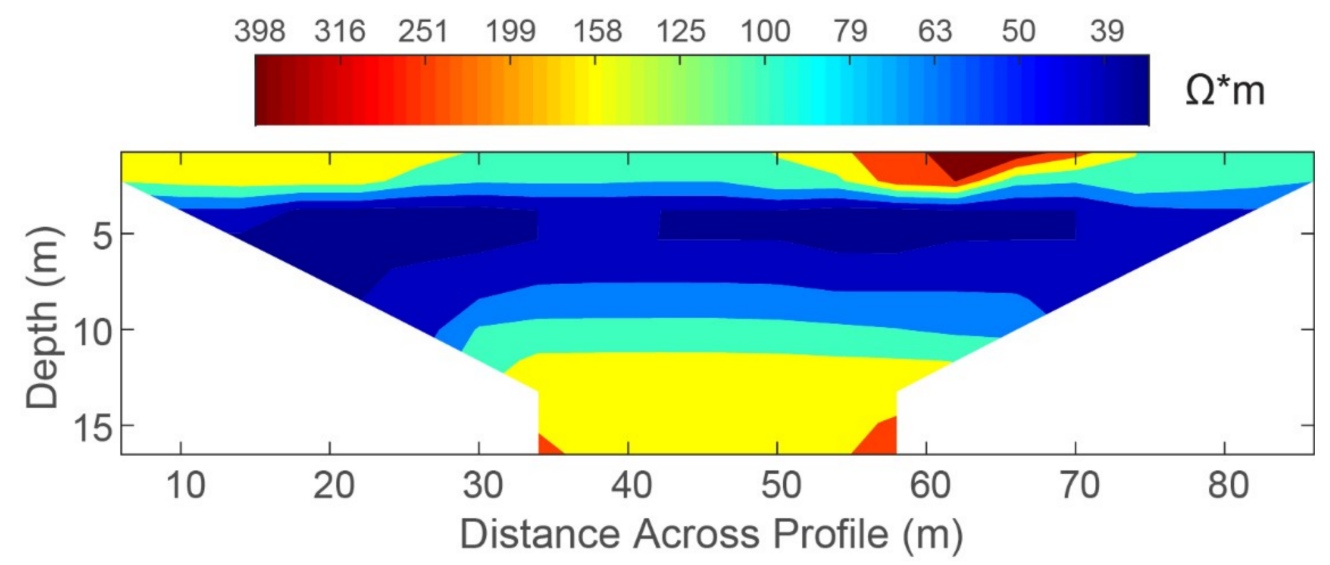

Figure 4. Inverted electrical resistivity tomography profile in Marian Meadow. Profile is on the southern side of Highway 36 (Figure 1B). Left side of profile strikes northeast. The profile consisted of 24 electrodes at a spacing of four-meters. The bottom corners (red color) of the model show small numerical artifacts of the inversion process, typical of electrical resistivity inversions.

\subsection{Statistical Analysis for Change Detection}

Standard least squared regression and analysis of covariance (ANCOVA) were used to test changes in weekly average groundwater depth and volumetric soil moisture content. Only measured groundwater values, no recession curve calculated values, were included in this analysis. The time periods when both meadows were fully saturated were excluded from the regression analysis. All assumptions of regression were tested including linearity, serial autocorrelation, normal distribution, and homoscedasticity. To account for serial autocorrelation an identified lag of three weeks was used for all soil moisture and water table depth analysis to ensure independence of the measurements.

\subsection{Durations of Depth to Water Table for Meadow Vegetation}

To determine the influence of water table depth on meadow vegetation the average, minimum, and maximum water table depths were identified for the growing season (May-August). Additionally, the duration (days) of water table depths below $0.7 \mathrm{~m}$ and $0.3 \mathrm{~m}$ were isolated. The measured duration of water table depths below $0.7 \mathrm{~m}$ and $0.3 \mathrm{~m}$ were compared to published durations for obligate wetland and facultative wetland plants species as defined by Hammersmark et al. [15].

\subsection{Meadows' Water Budgets}

To quantify the different hydrologic changes from the removal of encroached conifers we calculated different components of a water budget using precipitation, soil moisture, and groundwater depth changes following methods developed by Rahgozar et al. [35]. The water budget components were represented by WY. The general form of the water budget is (Equation (2)):

$$
P=\mathrm{Q}_{\mathrm{SEOF}}+\mathrm{ET}+/-\Delta \mathrm{S}
$$

where $P$ is precipitation $(\mathrm{mm})$ from the Chester rain gauge, $\mathrm{Q}_{\mathrm{SEOF}}$ is saturated excess overland flow $(\mathrm{mm}), \Delta S$ is change in water stored in the soil or groundwater $(\mathrm{mm})$, and ET is the sum of evapotranspiration from the soil and evaporation from interception capture $(\mathrm{mm})$.

\subsubsection{Saturated Excess Overland Flow (Q $\mathrm{SEOF})$}

The capillary fringe of the meadow was determined to be $0.1 \mathrm{~m}$ based on well elevations and observation of overland flow or ponding on the ground surface. Saturated excess overland flow $\left(\mathrm{Q}_{\mathrm{SEOF}}\right.$ ) was assumed to occur when the depth to water table was $<0.1 \mathrm{~m}$. Precipitation during that 
time period was assumed to be $\mathrm{Q}_{\mathrm{SEOF}}$. A water depth recorder manufactured by Odyssey Dataflow Systems Pty. Limited installed at a culvert at the downstream end of Marian Meadow was used to validate and adjust time periods when $\mathrm{Q}_{\mathrm{SEOF}}$ Occurred. We assume $\mathrm{Q}_{\mathrm{SEOF}}$ is water that either flows out of the meadows or evaporated when ponded on the meadows' ground surface.

\subsubsection{Infiltration (I) and Change in Storage $(\Delta S)$}

The infiltration of precipitation (I; Equation (3)) into the soil and aquifer was represented by the sum of increases in soil moisture $\left(\mathrm{I}_{\mathrm{s}}\right)$ over the year and the change in water table elevation $\left(\mathrm{I}_{\mathrm{wt}}\right)$ above a datum.

$$
\mathrm{I}=\mathrm{I}_{\mathrm{S}}+\mathrm{I}_{\mathrm{wt}}
$$

Infiltration in the unsaturated soil $\left(\mathrm{I}_{\mathrm{S}}\right)$ was evaluated for all soil moisture sensors at 2-hour intervals (time duration between measurements). When an increase in soil moisture occurred in a 2-hour interval the change in volumetric soil moisture was converted to a depth ( $\mathrm{mm}$ ) based on the unsaturated depth of soil (difference in surface elevation and water table elevation) [35]. The soil moisture sensors installed at $0.3 \mathrm{~m}$ and $0.9 \mathrm{~m}$ depth were assumed to be representative of soil $<0.6$ and $>0.6 \mathrm{~m}$ depth respectively. The $\mathrm{I}_{\mathrm{S}}$ values were summed for each soil moisture sensor and depth then averaged by WY.

The infiltration to the soil $\left(I_{\mathrm{s}}\right)$ does not account for the water that passes through to the saturated soil or water table. Infiltration to the saturated soil or water table $\left(\mathrm{I}_{\mathrm{wt}}\right)$ was calculated from the difference in average annual water table elevation between the most downstream groundwater well from the most upstream groundwater well. We assume that the upstream groundwater well is indicative of groundwater levels coming into the meadow and increases in the water table downstream represent infiltration from precipitation.

Storage of water in the sub-surface was the sum of groundwater and soil moisture minus ET $_{\mathrm{S}}$. This was represented by the difference in infiltration (I) and soil evapotranspiration (ET $)$ (Equation (4)).

$$
\Delta \mathrm{S}=\left(\mathrm{I}_{\mathrm{S}}+\mathrm{I}_{\mathrm{wt}}\right)-\mathrm{ET}_{\mathrm{S}}
$$

\subsubsection{Evapotranspiration (ET)}

Evapotranspiration is the sum of soil evapotranspiration and evaporation from interception capture of vegetation. Evapotranspiration from the soil $\left(\mathrm{ET}_{\mathrm{S}}\right)$ was evaluated for all soil moisture sensors at 2-hour intervals. When a decrease in soil moisture occurred in a 2-hour interval the change in volumetric soil moisture was converted to a depth $(\mathrm{mm})$ based on the unsaturated depth of soil [34]; an approach similar to a single layer single step (slss) calculation [38]. $\mathrm{ET}_{\mathrm{S}}$ for each WY were the averaged totals for all soil moisture sensors in each meadow. In a given time step ( $2 \mathrm{~h})$, depending on the algebraic sum of terms on the right-hand side of (Equation (2)), either soil infiltration or soil evapotranspiration is assumed to be occurring. An inherent assumption made here is that, since small time intervals $(2 \mathrm{~h})$ were used for the analysis, either evapotranspiration or infiltration took place in a given time step [35].

Interception capture (Ic) is the initial abstraction from a rainfall event. If there is no runoff accompanying a given rainfall event, then, theoretically, it can be estimated by subtracting the observed rainfall from the observed infiltration [35]. Interception capture was estimated by selecting isolated precipitation events with intensity less than the hydraulic conductivity of the surface soil layers, occurring after medium to dry antecedent conditions. The intercept of the best fit line on the precipitation to infiltration relationship yields the estimate of the interception capture. Interception capture (Ic) was assumed to represent either evaporation or sublimation of incoming precipitation. We further assume that the proportion of precipitation calculated for interception capture in dry to medium antecedent conditions applies to wet antecedent conditions. 


\section{Results}

\subsection{Statistical Analysis}

\subsubsection{Soil Moisture}

The mean Control Meadow and Marian Meadow soil moisture content prior to and following restoration were statistically different from one another ( $\mathrm{P}$ value $<0.0001$ ) (Figures 5 and 6). The intercept and slope of Marian Meadow soil moisture content pre- and post-restoration regression lines were statistically different from one another (P value $<0.0001)$ (Figure 5 ). The decrease in the intercept and increase in slope of the regression lines suggest that during dry periods, with lower soil moisture, the restored meadow had decreased soil moisture compared to the pre-restoration relationship (Figure 6). During wetter periods the post-restoration soil moisture in Marian Meadow increased compared to the pre-restoration soil moisture (Figures 4 and 5). The equations for the pre-restoration relationship for soil moisture percentage (Equation (5)) and one-year post-restoration relationship for soil moisture percentage (Equation (6)) were:

Marian Meadow Weekly Average Soil Moisture $(\%)=12.21+$ $0.63 \times$ Control Meadow Weekly Average Soil Moisture (\%)

Marian Meadow Weekly Average Soil Moisture $(\%)=9.40+$ $1.20 \times$ Control Meadow Weekly Average Soil Moisture (\%)

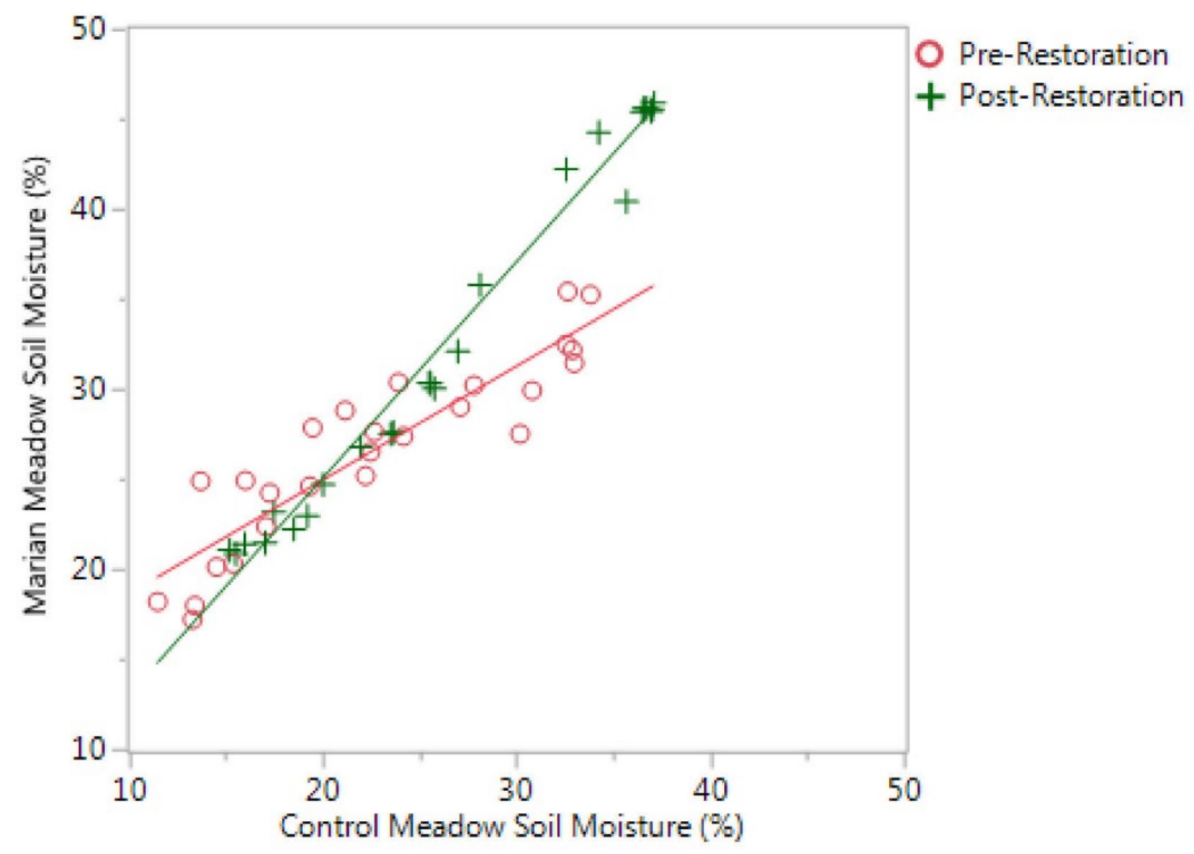

Figure 5. Regression analysis for the Control Meadow and Marian Meadow for pre- and post-restoration soil moisture percentage. Regression analysis based on average weekly measured soil moisture with a lag of three weeks between data points to avoid serial autocorrelation. 


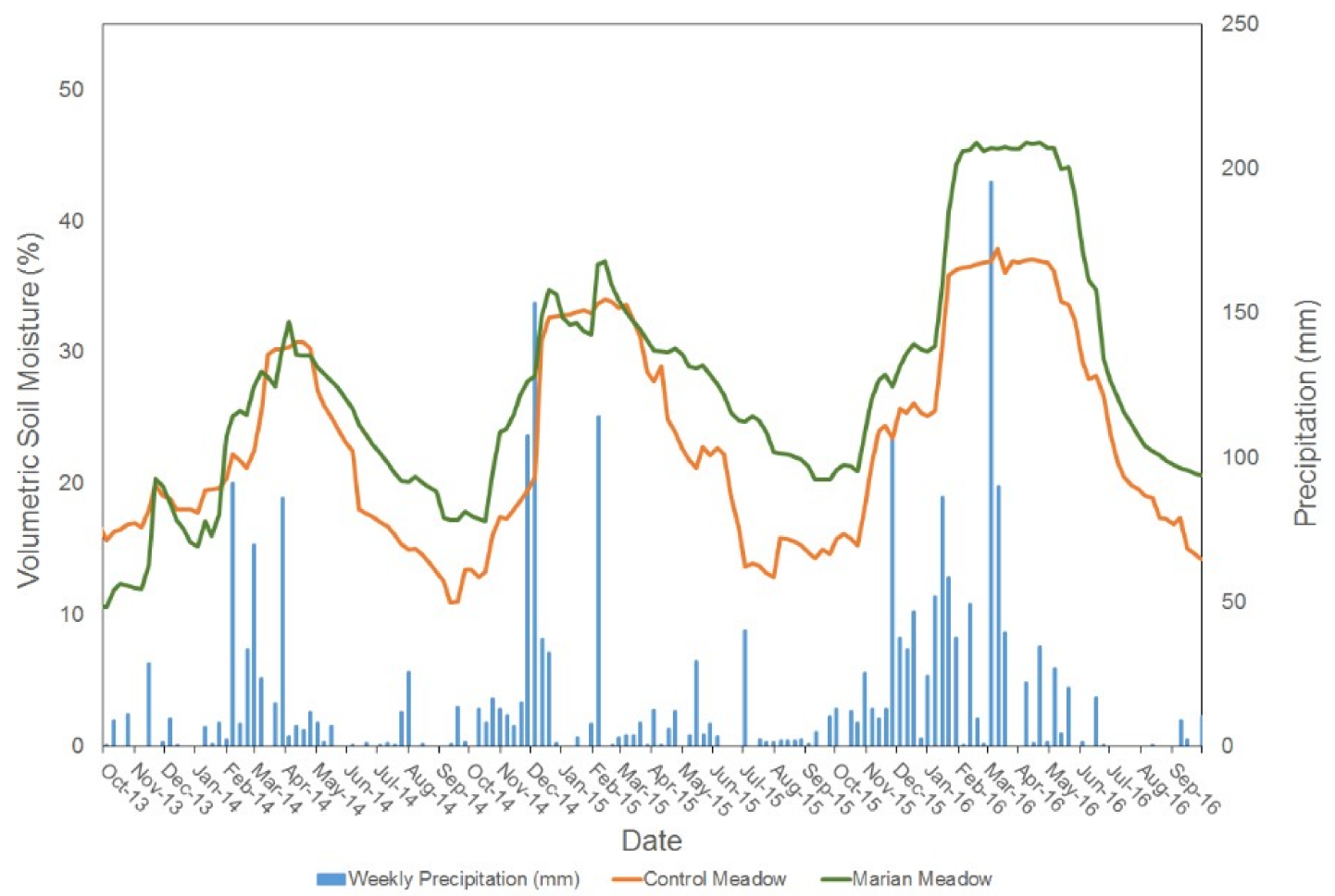

Figure 6. Marian and Control Meadows percent volumetric soil moisture content (\%) and weekly rainfall total $(\mathrm{mm})$.

\subsubsection{Water Table Depth}

Mean water table depth between the Control Meadow and Marian Meadow pre- and post-restoration were significantly different $(\mathrm{P}<0.0001)$ (Figures 7 and 8$)$. The intercept of Marian Meadow water table depth pre- and post-restoration were significantly different from one another indicating a $0.15 \mathrm{~m}$ decrease in water table depth $(\mathrm{P}<0.0001)$ (Figure 7$)$. The slopes of pre- and post-restoration depth to groundwater regression models were not significantly different $(P=0.48)$ (Figure 7). The increase in the intercept with no change in slope of the regression lines shows that the depth to groundwater increase was consistent throughout the year post-restoration. The regression equations used to predict Marian Meadow depth to groundwater pre-restoration (Equation (7)) and one-year post-restoration (Equation (8)) were:

Marian Meadow depth to groundwater $(\mathrm{m})=0.23+$ $0.77 \times$ Control Meadow depth to groundwater $(\mathrm{m})$

Marian Meadow depth to groundwater $(\mathrm{m})=0.08+$ $0.77 \times$ Control Meadow depth to groundwater $(\mathrm{m})$ 


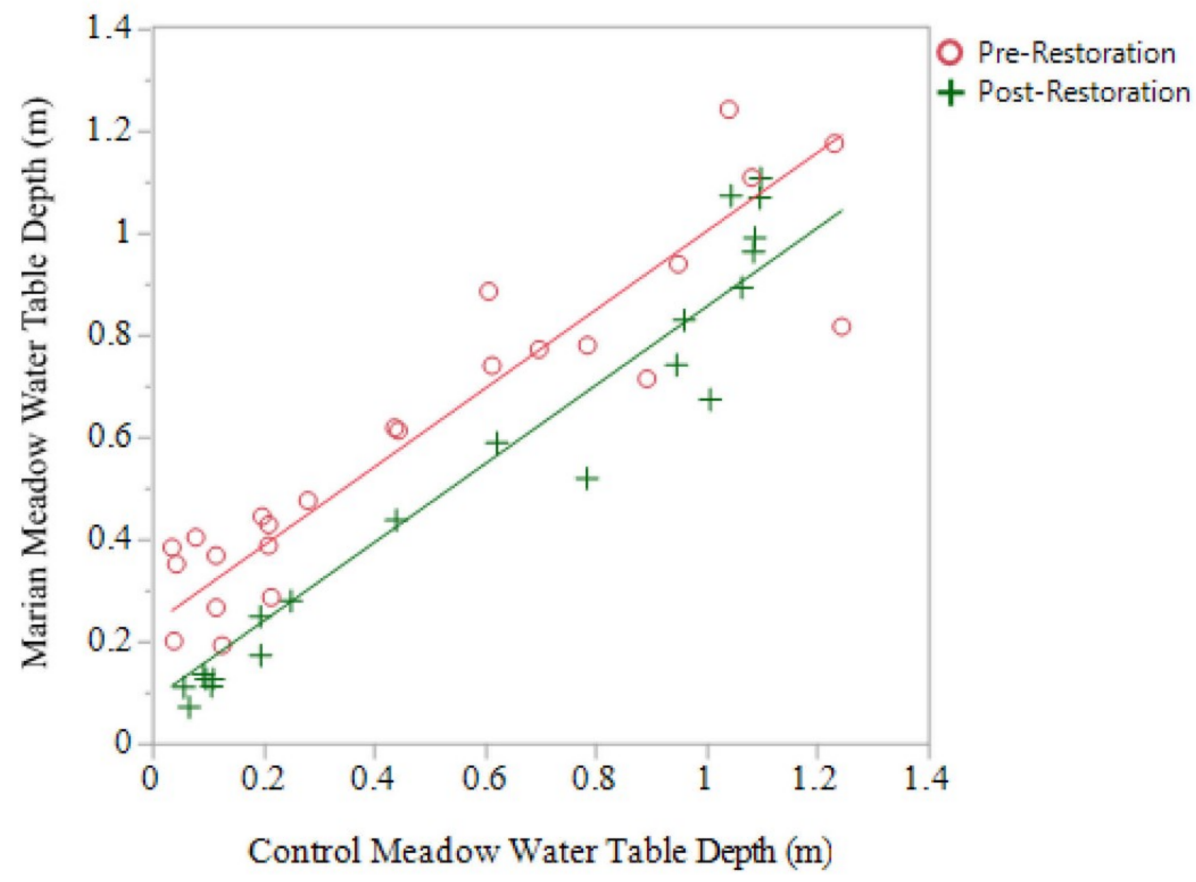

Figure 7. Regression analysis for the Control Meadow and Marian Meadow for pre- and post-restoration water table depth (depth to groundwater from the surface). Regression analysis based on average weekly measured water table depths with a lag of three weeks between data points to avoid serial autocorrelation.

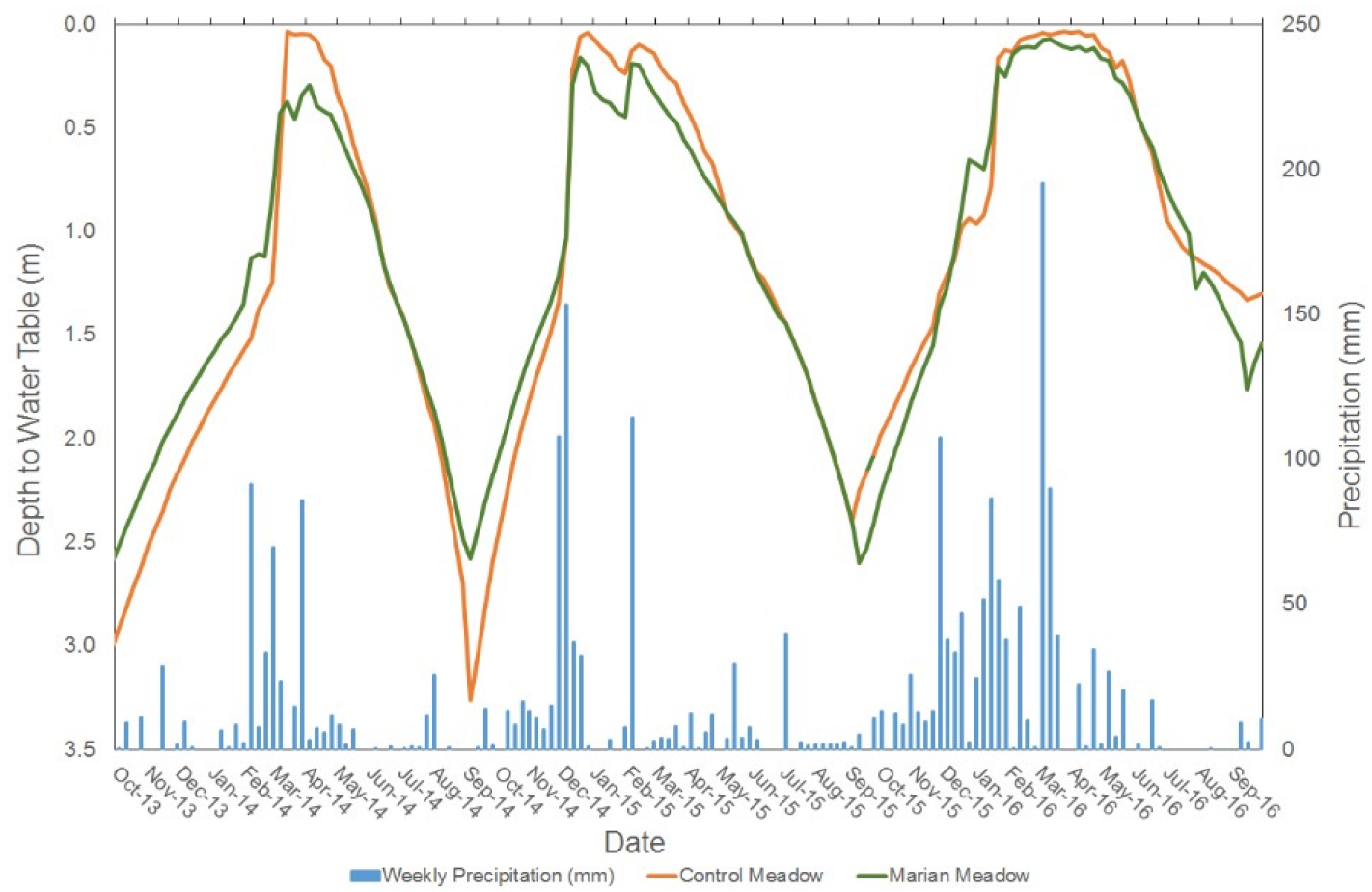

Figure 8. Depth to groundwater (m) and rainfall ( $\mathrm{mm})$ for Marian Meadow and the Control Meadow.

\subsection{Growing Season Durations at Rooting Depths}

Pre-restoration, 2014 and 2015 WY, Marian Meadow had greater average water table depths compared to the Control Meadow and fewer days with water table depths less than $0.3 \mathrm{~m}$ and $0.7 \mathrm{~m}$ (Table 2). The year following restoration Marian Meadow's average growing season water table depth of $0.3 \mathrm{~m}$ was comparable to the Control Meadow water table depth of $0.3 \mathrm{~m}$. Post-restoration growing 
season days with water table depths $<0.7 \mathrm{~m}$ and $<0.3 \mathrm{~m}$ were higher and relatively equal for Marian Meadow compared to the Control Meadow, respectively.

Table 2. Growing season (1 April through 31 August) water table depths (m) and number of days water table depths were $<0.7 \mathrm{~m}$ and $<0.3 \mathrm{~m}$ for Marian Meadow and the Control Meadow for WY 2014-2016.

\begin{tabular}{ccccccc}
\hline & \multicolumn{3}{c}{ Marian Meadow } & \multicolumn{3}{c}{ Control Meadow } \\
\cline { 2 - 7 } & $\mathbf{2 0 1 4} \mathbf{~ W Y}$ & $\mathbf{2 0 1 5} \mathbf{~ W Y}$ & $\mathbf{2 0 1 6} \mathbf{W Y}$ & $\mathbf{2 0 1 4} \mathbf{~ W Y}$ & $\mathbf{2 0 1 5} \mathbf{~ W Y}$ & $\mathbf{2 0 1 6} \mathbf{W Y}$ \\
\hline average & 1.23 & 1.47 & 0.65 & 1.12 & 1.32 & 0.67 \\
minimum & 0.29 & 0.61 & 0.12 & 0.05 & 0.45 & 0.06 \\
maximum & 2.48 & 2.78 & 1.3 & 2.42 & 2.30 & 1.45 \\
Days $<0.7 \mathrm{~m}$ & 46 & 7 & 85 & 53 & 24 & 71 \\
Days $<0.3 \mathrm{~m}$ & 4 & 0 & 50 & 25 & 0 & 50 \\
\hline
\end{tabular}

\subsection{Meadow Water Budgets}

Annual observed water budget components in the Control Meadow with meadow vegetation (2014-2016), Marian Meadow pre-restoration (2014-2015), and post-restoration (2016) are summarized (Table 3). The variability in precipitation was large between the 3 years of study, with 2016 precipitation almost double 2014.

Table 3. Water budget of Marian and Control Meadows for pre-restoration 2014-2015 water years (WY) and one year following restoration by encroached conifer removal 2016 WY.

\begin{tabular}{cccccccccc}
\hline Location & $\mathbf{W Y}$ & $\boldsymbol{P}(\mathbf{m m})$ & $\mathbf{Q}_{\text {SEOF }}(\mathbf{m m})$ & $\mathbf{I}(\mathbf{m m})$ & $\left.\mathbf{I}_{\mathbf{w t}} \mathbf{( m m}\right)$ & $\mathbf{E T}_{\mathbf{S}}(\mathbf{m m})$ & $\mathbf{I c}(\mathbf{m m})$ & $\mathbf{E T}(\mathbf{m m})$ & Error $(\mathbf{m m})$ \\
\hline Pre-Marian & 2014 & 489 & 0 & 280 & 22 & 285 & 172 & 457 & 15 \\
Pre-Marian & 2015 & 636 & 107 & 267 & 40 & 268 & 214 & 482 \\
Post-Marian & 2016 & 931 & 433 & 308 & 90 & 318 & 107 & 425 & 9 \\
Control & 2014 & 489 & 75 & 255 & 79 & 286 & 74 & 360 & -7 \\
Control & 2015 & 636 & 102 & 267 & 103 & 258 & 87 & 345 \\
Control & 2016 & 931 & 374 & 333 & 42 & 288 & 107 & 395 & 78 \\
\hline
\end{tabular}

ET was similar for 2014-2016 WY for the Control Meadow (345-395 mm/yr) with the highest amount of evapotranspiration in $2016 \mathrm{WY}$ primarily due to greater interception evaporation from higher precipitation (Table 3). ET was $457 \mathrm{~mm} / \mathrm{yr}$ and $482 \mathrm{~mm} / \mathrm{yr}$ in Marian Meadow during the pre-restoration period of 2014 WY and 2015 WY respectively. ET was slightly lower in Marian Meadow, $425 \mathrm{~mm} / \mathrm{yr}$, for $2016 \mathrm{WY}$ following removal of encroached conifers. However, the 2016 amount of interception evaporation decreased by almost half of the pre-restoration times, even with higher annual precipitation.

ET values were similar in the Control and Marian Meadows all three years with the exception of higher evapotranspiration from the soil at Marian Meadow in 2016 WY, the year after conifer removal (Table 3). We attribute this higher level of soil evapotranspiration to the high amount of bare soil exposed during conifer removal. The most notable change in the year following conifer removal was the percentage of annual precipitation by ET decreased as precipitation increased (Table 4) with the 2016 WY having the lowest percentage. The percentage of ET for Marian Meadow was 20\% and 18\% higher in the pre-restoration period of 2014 WY and 2015 WY than the Control Meadow ET respectively. In the $2016 \mathrm{WY}$ following conifer removal the percentage of ET for Marian Meadow was similar to the Control Meadow, $46 \%$ and $42 \%$ of precipitation respectively. 
Table 4. Water budget percentage of precipitation for Marian and Control Meadows for pre-restoration 2014-2015 water years (WY) and one year following restoration by encroached conifer removal 2016 WY.

\begin{tabular}{ccccccc}
\hline Location & WY & $\boldsymbol{P}(\mathbf{m m})$ & $\mathbf{Q S E O F}_{\text {SE }} \mathbf{( \% )}$ & $\boldsymbol{\Delta S}(\mathbf{\%})$ & $\mathbf{E T ~ ( \% )}$ & Error (\%) \\
\hline Pre-Marian & 2014 & 489 & $0 \%$ & $3 \%$ & $94 \%$ & $-3 \%$ \\
Pre-Marian & 2015 & 636 & $17 \%$ & $6 \%$ & $76 \%$ & $-1 \%$ \\
Post-Marian & 2016 & 931 & $47 \%$ & $9 \%$ & $46 \%$ & $2 \%$ \\
Control & 2014 & 489 & $15 \%$ & $10 \%$ & $74 \%$ & $-1 \%$ \\
Control & 2015 & 636 & $16 \%$ & $18 \%$ & $54 \%$ & $-12 \%$ \\
Control & 2016 & 931 & $40 \%$ & $9 \%$ & $42 \%$ & $-9 \%$ \\
\hline
\end{tabular}

QSEOF for Marian Meadow and the Control Meadow were similar for 2015 and 2016 WY (Tables 3 and 4). In the 2014 WY Marian Meadow had no QSEOF while the Control Meadow had $75 \mathrm{~mm}$ of QSEOF. The 2014 WY had below average precipitation and Marian Meadow had considerably more interception evaporation than the Control Meadow, $172 \mathrm{~mm}$ compared to $74 \mathrm{~mm}$ respectively (Table 3). In 2015 WY and 2016 WY higher annual precipitation forced similar QSEOF values.

$\Delta S$ had differing responses between Marian Meadow and the Control Meadow. The Control Meadow had the highest increase in sub-surface water storage in 2015 WY (Table 4). While Marian Meadow had $\Delta S$ increase with precipitation, with the largest increase in the $2016 \mathrm{WY}$ following restoration by conifer removal. The difference between the meadows was an increase in $\mathrm{I}_{\mathrm{wt}}$ for Marian Meadow in $2016 \mathrm{WY}$ yet a decrease in $\mathrm{I}_{\mathrm{wt}}$ for the Control Meadow, $90 \mathrm{~mm}$ compared to $42 \mathrm{~mm}$ respectively (Table 3). At higher water tables the slope of water table surface in the Control Meadow decreased compared to Marian Meadow, suggesting differences in groundwater outflow during the high precipitation year.

\section{Discussion}

\subsection{Sub-Surface Water Change due to Conifer Removal}

The first year post-restoration there was a $0.15 \mathrm{~m}$ decrease between the measured and predicted water table depth. This represents a $13 \%$ decrease in average water table depth resulting in a gain of groundwater across Marian Meadow in the year following restoration. The water budget value of $\mathrm{I}_{\mathrm{Wt}}$ also showed change in the $2016 \mathrm{WY}$, however the change was predicted to be smaller, on average $0.06 \mathrm{~m}$. The difference between the estimates are likely a function of error in the use of water table diurnal changes, which at times could be difficult to isolate for $\mathrm{I}_{\mathrm{wt}}$ determination.

Post-restoration regression analysis showed Marian Meadow soil moisture content decreased during periods with relatively low soil moisture ( $<24 \%$ in Marian Meadow, Figure 5$)$. We suggest this was caused by not only reduction of vegetation cover but also an increase in direct sunlight to the soil surface creating higher soil temperatures creating increased evaporation of soil water [39]. The restoration process involved considerable ground disturbance in addition to the removal of the over story conifer canopy encroaching the meadow. $\mathrm{ET}_{\mathrm{S}}$ in the year following restoration was higher in Marian Meadow than when conifers were on the site. During periods with elevated soil moisture content ( $>24 \%$ in Marian Meadow), during the wet season, soil moisture increased in the first year post-restoration in Marian Meadow (Figure 3). We believe that the combination of a decrease in wet season transpiration and decreased interception losses (Ic, Table 4) from the removal of conifer canopy explains this increased soil moisture during the wet season.

The increase in soil moisture occurred in November 2015 (Figure 6). On average, Marian Meadow had a decrease in soil moisture the first year post-restoration, by $1.4 \%$ during the months of August through October and increased by $6.1 \%$ during the months of November through June. Overall, the differences in the regression equations for pre- and post-restoration showed an approximate $4 \%$ volumetric soil moisture content increase in Marian Meadow one year following restoration. 


\subsection{Evapotranspiration Response of Conifer Removal}

The expectation is the transition from a meadow with encroached lodgepole pine (forest vegetation) at a basal area of $25.04 \mathrm{~m}^{2} /$ hectare to a dry meadow habitat (grass and forb vegetation) will create lower ET e.g., [40,41]. Our water budget calculations were consistent with this statement. ET values for Marian Meadow with encroached lodgepole pine were 457 and $482 \mathrm{~mm} / \mathrm{yr}$ for the pre-restoration 2014-2015 WY. ET values for the Control Meadow, with seasonal forbs and grass, ranged from 345 to $395 \mathrm{~mm} / \mathrm{yr}$ for 2014-2016 WY. Marian Meadow in the 2016 WY, following removal of encroached conifers, was $425 \mathrm{~mm} / \mathrm{yr}$, only $6 \%$ higher than the $399 \mathrm{~mm} / \mathrm{yr}$ for the Control Meadow. Several studies have documented higher ET values for bare soil e.g., [42,43] offering a possible explanation for the higher 2016 WY ET value for Marian Meadow following the harvest disturbance for restoration.

ET calculated by the water budget was relatively similar through the 3 years of study at the Control Meadow and Marian Meadow, excepting 2016 WY following restoration on Marian Meadow (Table 3). This similarity between years for ET was observed by Christensen et al. [44]. They found ET in low lying areas, within elevations similar to Marian and Control Meadows, had little inter-annual variability due to topographic controlled high soil moistures. The similar annual $\mathrm{ET}_{\mathrm{S}}$ meant that the ET percentage of precipitation decreased as annual precipitation increased. Notably the ET percentage of precipitation converged between the Marian Meadow and Control Meadow in the 2016 WY following conifer removal, at $46 \%$ and $42 \%$ of precipitation respectively (Table 4 ).

The primary ET process altered by the restoration from removal of encroached conifer was evaporation from interception (Table 3). When conifer vegetation was on Marian Meadow interception losses were approximately 35\% and 34\% of precipitation in $2014 \mathrm{WY}$ and $2015 \mathrm{WY}$ respectively. Following conifer removal interception reduced to $11 \%$ of precipitation in 2016 WY. In our study meadows reduction of interception evaporation was the primary process forcing a decrease in depth to water table and small soil moisture increases following conifer removal.

\subsection{Depth to Water Table Promoting Meadow Vegetation}

During the 2014 growing season and prior to restoration, both Marian Meadow and Control Meadow experienced groundwater depths deeper than $1 \mathrm{~m}$, indicative of a dry meadow as classified by Weixelman et al. [14]. Although 2014 was a drought year, there were significant periods of time that the groundwater was within the rooting zone of $0.7 \mathrm{~m}$ of common dry meadow plant species as defined by Hammersmark et al. [45]. During the 2015 growing season, neither meadow experienced groundwater depths indicative of dry meadow plant species. However, if the post-restoration water table depth regression equation is applied to the 2015 average growing season water table depth, it is predicted that in Marian Meadow the average growing season water table depth would have reduced from $1.47 \mathrm{~m}$ (measured average value) to $1.03 \mathrm{~m}$ (predicted average value). This suggests that even in a drought year, where a significant amount of the precipitation fell prior to January, Marian Meadow would have exhibited growing season water table depths representative of a dry meadow.

Following restoration, Marian Meadow had growing season water table depths similar to meadows that are dominated by Poa pratensis and Bromus japonicas, which are facultative and facultative upland species common in dry meadows [43]. When assessing the number of days the water table depth was less than $0.7 \mathrm{~m}$ and $0.3 \mathrm{~m}$, Marian Meadow exhibited growing season water table depths similar to plots with a high proportion of obligate and facultative wetland species. The obligate and facultative wetland species had water table depths less than or equal to $0.7 \mathrm{~m}$ for approximately 65 days, and the water table was within $0.3 \mathrm{~m}$ from the surface for $42-47$ days. In this study, the post-restoration water table depth of Marian Meadow was less than or equal to $0.7 \mathrm{~m}$ and $0.3 \mathrm{~m}$ for 85 days and 50 days, respectively (Table 2). Although the climate at Marian Meadow is unlikely to produce conditions at low water table depths conducive for wetland obligate species every year, the results indicate hydrologic conditions post-restoration conducive to promoting meadow vegetation. 


\section{Conclusions}

Statistical analysis indicates that following conifer removal on Marian Meadow, there was an increase in volumetric soil moisture content of $4 \%+/-0.6 \%$. The slope and intercept of the regression relationship between soil moisture for Marian Meadow and the Control Meadow were statistically different. The change in slope of the post-restoration relationship indicated lower soil moisture, during the dry period and higher soil moisture in the wet period of the year. This was additionally evident in increased soil evapotranspiration the first year post-restoration. Marian Meadow had 30-50 mm greater soil evapotranspiration the first year following restoration activities than the Control Meadow's previous 3 years and Marian Meadows previous 2 pre-restoration years. The statistical analysis also indicated that following restoration by conifer removal, the depth to the water table decreased on average by $0.15 \mathrm{~m}+/-0.03 \mathrm{~m}$. The increases in soil moisture and decrease in water table depth we attribute primarily to a reduction of approx. $23 \%$ of precipitation inputs by interception evaporation following removal of encroached conifer trees.

Marian Meadow for the one year following restoration exhibited growing season water table depths consistent with meadow plant species. The duration of post-restoration water table depths at Marian Meadow were less than or equal to $0.7 \mathrm{~m}$ and $0.3 \mathrm{~m}$ for 85 days and 50 days, respectively. This indicated conditions supportive of wetland obligate species. Due to its classification as a dry meadow Marian Meadow is unlikely to produce conditions conducive for wetland obligate species every year. The first year post-restoration results indicate hydrologic conditions that are conducive to promote meadow vegetation.

Author Contributions: Conceptualization, C.S.; Formal analysis, C.S., T.S., G.V. and J.J.; Funding acquisition, C.S.; Investigation, C.S., T.S., G.V. and J.J.; Methodology, C.S., T.S. and G.V.; Project administration, C.S.

Funding: This research was funded by grants from the California State Universities Agriculture Research Institute grant number ARI-03-020 and USDA-NIFA-McIntire-Stennis funds grant number CALY-1302.

Acknowledgments: The Collins Pine Company supported this research by allowing access to their land, conducting the harvest for restoration of Marian Meadow, housing for field measurement trips, forest stand information, and GIS data.

Conflicts of Interest: The authors declare no conflict of interest.

\section{References}

1. Halpern, C.; Haugo, R.; Antos, J.; Kaas, S.; Kilanowski, A. Grassland restoration with and without fire: Evidence from a tree-removal experiment. Ecol. Appl. 2012, 22, 425-441. [CrossRef] [PubMed]

2. Mcllroy, S.; Allen-Diaz, B. Plant community distribution along water table and grazing gradients in montane meadows of the Sierra Nevada Range (California, USA). Wetl. Ecol. Manag. 2012, 20, 287-296. [CrossRef]

3. Viers, J.; Purdy, S.; Peek, R.; Fryjoff-Hung, A.; Santos, N.; Katz, J.; Emmons, J.; Dolan, D.; Yarnell, S. Montane Meadows in the Sierra Nevada: Changing Hydroclimatic Conditions and Concepts for Vulnerability Assessment; Center for Watershed Sciences Technical Report (CWS-2013-01); University of California: Davis, CA, USA, 2013; 63p.

4. Norton, J.; Olsen, H.; Jungst, L.; Legg, D.; Horwath, W. Soil carbon and nitrogen storage in alluvial wet meadows of the Southern Sierra Nevada Mountains, USA. J. Soils Sediments 2013, 14, 34-43. [CrossRef]

5. Tokarczyk, N. Forest encroachment on temperate mountain meadows-Scale, drivers, and current research directions. Geogr. Pol. 2017, 90, 463-480. [CrossRef]

6. Shaw, A. Conservation and Ecological Restoration of Rocky Mountain Subalpine Meadows: Vegetation Responses to Tree Encroachment. Master's Thesis, University of Victoria, Victoria, BC, Canada; 109p.

7. Burns, R.; Honkala, B. Silvics of North America: Conifers. Agriculture Handbook 654; U.S. Department of Agriculture, Forest Service: Washington, DC, USA, 1990; Volume 1, 675p.

8. Takaoka, S.; Swanson, F. Change in Extent of Meadows and Shrub Fields in the Central Western Cascade Range, Oregon. Prof. Geogr. 2008, 60, 527-540. [CrossRef] 
9. Gross, S.; Coppoletta, M. Historic Range of Variability for Meadows in the Sierra Nevada and South Cascades; United States Department of Agriculture Forest Service: Davis, CA, USA, 2013. Available online: http: / / www.fs.usda.gov/Internet/FSE_DOCUMENTS/stelprdb5434345.pdf (accessed on 24 July 2014).

10. Taylor, A. Tree invasion in meadows of Lassen Volcanic National Park. Calif. Prof. Geogr. 1990, 42, 457-470. [CrossRef]

11. Ratliff, R. Meadows in the Sierra Nevada of California: State of Knowledge; Gen. Tech. Report PSW-84; USDA Forest Service: Davis, CA, USA, 1985; 59p.

12. Vankat, J. Fire and man in Sequoia National Park. Ann. Assoc. Am. Geogr. 1977, 67, 17-27. [CrossRef]

13. Chambers, J.; Miller, J.; Germanoski, D. Geomorphology, Hydrology, and Ecology of Great Basin Meadow Complexes_Implications for Management and Restoration; Gen. Tech. Rep. RMRS-GTR-258; U.S. Department of Agriculture, Forest Service, Rocky Mountain Research Station: Fort Collins, CO, USA, 2011; 125p.

14. Weixelman, D.; Hill, B.; Cooper, D.; Berlow, E.; Viers, J.; Purdy, S.; Merrill, A.; Gross, S. Meadow Hydrogeomorphic Types for the Sierra Nevada and Southern Cascades Ranges in California: A Field Key; Gen. Tech. Rep. R5-TP-034; USDA Forest Service: Fort Collins, CO, USA, 2011.

15. Hammersmark, C.; Rains, M.; Wickland, A.; Mount, J. Vegetation and water-table relationships in a hydrologically restored riparian meadow. Wetlands 2009, 29, 785-797. [CrossRef]

16. Knowles, N.; Dettinger, M.; Cayan, D. Trends in snowfall versus rainfall in the western United States. J. Clim. 2006, 19, 4545-4559. [CrossRef]

17. Hamlet, A.; Carrasco, P.; Deems, J.; Elsner, M.; Kamstra, T.; Lee, C.; Lee, S.-Y.; Mauger, G.; Salathe, E.; Tohver, I.; et al. Final Project Report for the Columbia Basin Climate Change Scenarios Project; Climate Impacts Group: Seattle, WA, USA, 2010.

18. Surfleet, C.; Tullos, D. Uncertainty assessment of hydrologic response to climate change for the Santiam River, Oregon. Hydrol. Process. 2012. [CrossRef]

19. Loheide, S.; Lundquist, J. Snowmelt-induced diel fluxes through the hyporheic zone. Water Resour. Res. 2009, 45, 1-9. [CrossRef]

20. Loheide, S.; Gorelick, S. Riparian hydroecology: A coupled model of the observed interactions between groundwater flow and meadow vegetation patterning. Water Resour. Res. 2007, 43, 1-16. [CrossRef]

21. Haugo, R.; Halpern, C. Vegetation responses to conifer encroachment in a Western Cascade meadow: A chronosequence approach. Botany 2007, 85, 285-298. [CrossRef]

22. Stillwater Sciences. A Guide for Restoring Functionality to Mountain Meadows of the Sierra Nevada. 2012. Available online: http:/ / www.stillwatersci.com/resources/2012meadowrestguide.pdf (accessed on 17 November 2014).

23. Keppeler, E.; Ziemer, R. Logging effects on streamflow: Water yield and summer low flows at Caspar Creek in northwestern California. Water Resour. Res. 1990, 26, 1669-1679. [CrossRef]

24. Adams, P.W.; Flint, A.L.; Fredriksen, R.L. Long-term patterns in soil moisture and revegetation after a clearcut of a Douglas-fir forest in Oregon. For. Ecol. Manag. 1991, 41, 249-263. [CrossRef]

25. Surfleet, C.; Skaugset, A. The effect of timber harvest on summer low flows, Hinkle Creek, Oregon. West. J. Appl. For. 2013, 28, 13-21. [CrossRef]

26. Mitsch, W.; Gosselink, J. The value of wetlands: Importance of scale and landscape setting. Ecol. Econ. 2000, 35, 25-33. [CrossRef]

27. California Data Exchange Center. California Department of Water Resources. 2015. Available online: http:/ / cdec.water.ca.gov / misc/DailyPrecip.html (accessed on 29 January 2015).

28. Miles, S.; Goudey, C. Ecological Subregions of California Section E Subsection Descriptions; United States Department of Agriculture Forest Service, Pacific Southwest Region: Washington, DC, USA, 1997.

29. Soil Survey Staff. Web Soil Survey: Soil Data Mart. USDA-NRCS. Available online: http:/ / websoilsurvey. nrcs.usda.gov (accessed on 15 December 2017).

30. United States Department of Agriculture, Natural Resources Conservation Service. Field Indicators of Hydric Soils in the United States; Version 7.0.; Vasilas, L.M., Hurt, G.W., Noble, C.V., Eds.; USDA, NRCS, in Cooperation with the National Technical Committee for Hydric Soils: Washington, DC, USA, 2010.

31. Carman, P.C. Flow of Gases through Porous Media; Butterworth Scientific Publications: London, UK, 1956; 182p.

32. Bouyoucos, G.J. Hydrometer Method Improved for Making Particle Size Analyses of Soils. Agron. J. 1962, 54, 464-465. [CrossRef] 
33. VanOosbree, G. Hydrologic Response from Conifer Removal from an Encroached Meadow. Master's Thesis, Cal Poly, San Luis Obispo, CA, USA, 2016; 179p.

34. Sanford, T. The Water Table and Soil Moisture Response Following the Removal of Conifers from an Encroached Meadow. Master's Thesis, California Polytechnic State University, San Luis Obispo, CA, USA, 2016; 103p.

35. Rahgozar, M.; Shah, N.; Ross, M. Estimation of evapotranspiration and water budget components using concurrent soil moisture and water table monitoring. ISRN Soil Sci. 2012, 2012, 726806. [CrossRef]

36. Black, C.; Evans, D.; Dinauer, R. Methods of soil analysis. Am. Soc. Agron. 1965, 9, 653-708.

37. Telford, W.; Geldart, L.; Sheriff, R. Applied Geophysics, 2nd ed.; Cambridge Press: Cambridge, UK, 1991.

38. Guderle, M.; Hildebrandt, A. Using Measured Soil Water Contents to Estimate Evapotranspiration and Root Water Uptake Profiles-a Comparative Study. Hydrol. Earth Syst. Sci. 2015, 19, 409-425. [CrossRef]

39. Penman, H. Natural evaporation from open water, bare soil and grass. Proc. R. Soc. A 1947, 193, $120-145$. Available online: http:/ / rspa.royalsocietypublishing.org/ (accessed on 6 January 2018).

40. Lucas, R.; Conklin, M.; Goulden, M. Montane meadow evapotranspiration: Implications for restoration and impacts on downstream flow. In Proceedings of the H11E Interacting Physical and Ecological Processes across Terrestrial and Aquatic Systems I Posters, 2015 Fall Meeting, AGU, San Francisco, CA, USA, 14-18 December 2015.

41. Zhang, L.; Dawes, W.; Walker, G. Response of mean annual evapotranspiration to vegetation changes at catchment scale. Water Resour. Res. 2001, 37, 701-708. [CrossRef]

42. Fisher, J.; DeBiase, T.; Qi, Y.; Xu, M.; Goldstein, A. Evapotranspiration models compared on a Sierra Nevada forest ecosystem. Environ. Model. Softw. 2005, 20, 783-796. [CrossRef]

43. Barton, I.J. A Parameterization of the Evaporation from Nonsaturated Surfaces. J. Appl. Meteorol. 1979, 18, 43-47. [CrossRef]

44. Christensen, L.; Tague, C.; Baron, J. Spatial patterns of simulated transpiration response to climate variability in a snow dominated mountain ecosystem. Hydrol. Process. 2008, 22, 3576-3588. [CrossRef]

45. Hammersmark, C.; Dobrowski, S.; Rains, M.; Mount, J. Simulated Effects of Stream Restoration on the Distribution of Wet-Meadow Vegetation. Restor. Ecol. 2010, 18, 882-893. [CrossRef] 